\title{
Meaning of Rocks Basic Enclaves in the Eburnean Granitoids of Mako Area (Kédougou-Kéniéba Inlier, Senegal): Petrogenetic Implications
}

\author{
Ibrahima Gassama, Moussa Dabo*, Mamadou Ndiaye, Emmanuel Tama Samoura, \\ Fatou Bop Ndong
}

Université Cheikh Anta Diop de Dakar, Département de Géologie, Dakar, Sénégal

Email: ^moussa.dabo@ucad.edu.sn

How to cite this paper: Gassama, I., Dabo, M., Ndiaye, M., Samoura, E.T. and Ndong, F.B. (2021) Meaning of Rocks Basic Enclaves in the Eburnean Granitoids of Mako Area (Kédougou-Kéniéba Inlier, Senegal): Petrogenetic Implications. International Journal of Geosciences, 12, 39-56.

https://doi.org/10.4236/ijg.2021.121004

Received: November 20, 2020

Accepted: January 26, 2021

Published: January 29, 2021

Copyright $\odot 2021$ by author(s) and Scientific Research Publishing Inc. This work is licensed under the Creative Commons Attribution International License (CC BY 4.0).

http://creativecommons.org/licenses/by/4.0/

\begin{abstract}
The Mako area, located in eastern Sénégal, constitutes a segment of Paleoproterozoic (Birimian) formations of the Kédougou-Kéniéba Inliers (KKI) in the western part of the West African craton. The basic volcanism of the Birimian formations of the KKI has long been considered to be related to a single magmatic event associated with a Mid Oceanic Ridge Basalts (MORB) setting. The aim of this paper is to demonstrate on the basis of the architectural characteristics of the granitoids dark enclaves, the occurrence of at least two distinct phases of basic Magamtism in the Birimian of the KKI. The methodology consists of a cartography, a petrographic and architectural characterization of the dark enclaves within the Mako granitoids, in order to constrain their spatial and temporal relationships with the granitic magma. The results obtained are compared with those of the bibliography. We have pinpointed two types of enclaves depending on their shapes and the characteristics of their edge with the enclosing rocks: angular enclaves with straight edges (antegranitoids) and the soft enclaves with uneven edges (syn-granitoids). The enclaves with straight and well-defined rectilinear edges (ante-granitoids) would be linked to a basic magma which is already consolidated before being fragmented, torn and carried away as enclaves in the granitoids. These enclaves would come from enclosing outcrops of metabasalts and metagabbros which are locally cross-cut by the granitoids. The soft enclaves with uneven edges (syn-granitoids) were co-magmatic and not solid during their incorporation into the granitoids. They come from a basic magma which is contemporaneous to the granitic one. Thus, the occurrence of two generations of dark enclaves is related to, at last, two different phases of basic magmatism in the Birimian formations of the KKI.
\end{abstract}




\section{Keywords}

Paleoproterozoic, Kédougou-Kéniéba, Mako, Granitoids, Basic Enclave, Birimian

\section{Introduction}

The Kédougou-Kéniéba Inlier (KKI) is the most western part of the Birimian formations of the Léo-Man shield in the West African Craton (WAC) (Figure 1). It has been the subject of many geological studies which were based on geochemistry, geochronology, and the tectonic ([1] [2] [3] [4]). In the Mako area (Southeast of the Mako Supergroup), the Birimian formations are constituted by a large variety of rocks ranging from ultrabasic and basic to intermediary and acid associated with some sedimentary rocks. Those Birimian formations are intersected by Eburnean granitoids, some of which contain enclaves of metavolcanic rocks mainly of basaltic nature.

The study of the basic enclaves is important because it sheds light on the mode of emplacement of granitic magma, the nature of the enclaves and the dynamics of the magmatic chambers at the origin of the process. It also allows us to determine the chronology of the acid and basic magmatic events.

Many questions can be asked concerning the origin and significance of enclaves of basic rocks in the granitoids of Mako area.

Are these enclaves, were fragments of rocks washed away by the magma which is at the origin of the formation of the granitoids?

Do these enclaves come from a basic magma which mixed with the magma of granitoids?

We will answer these questions by determining the characteristics of the basic enclaves in the granitoids and their implication in the geodynamic processes of Birimian magmatism in the KKI. For this, we will rely on field and microscopic observations.

\section{Geological Setting}

The Man-Leo Rise in the south of the West African Craton (WAC) is made up of Archean-Paleoproterozoic rocks (Figure 1(a)). Paleoproterozoic formations of the WAC called "Birimian" ([5] [6]) correspond to a mixture of variably metamorphosed volcanic, plutonic, and sedimentary rocks which were formed over a relatively short period of time $(2.2-2.0 \mathrm{Ga})$ ([7] [8]). Paleoproterozoic inliers are found east of the craton between the two shields, and correspond to the Kayes in Mali and the Kédougou-Kéniéba straddles the border between Mali and Senegal.

The Kédougou-Kéniéba and the Kayes Inliers correspond to small cores of the Paleoproterozoic basement of the Man shield [6]. They outcrop in the West African Craton part within the Neoproterozoic to Palaeozoic sediments of the 


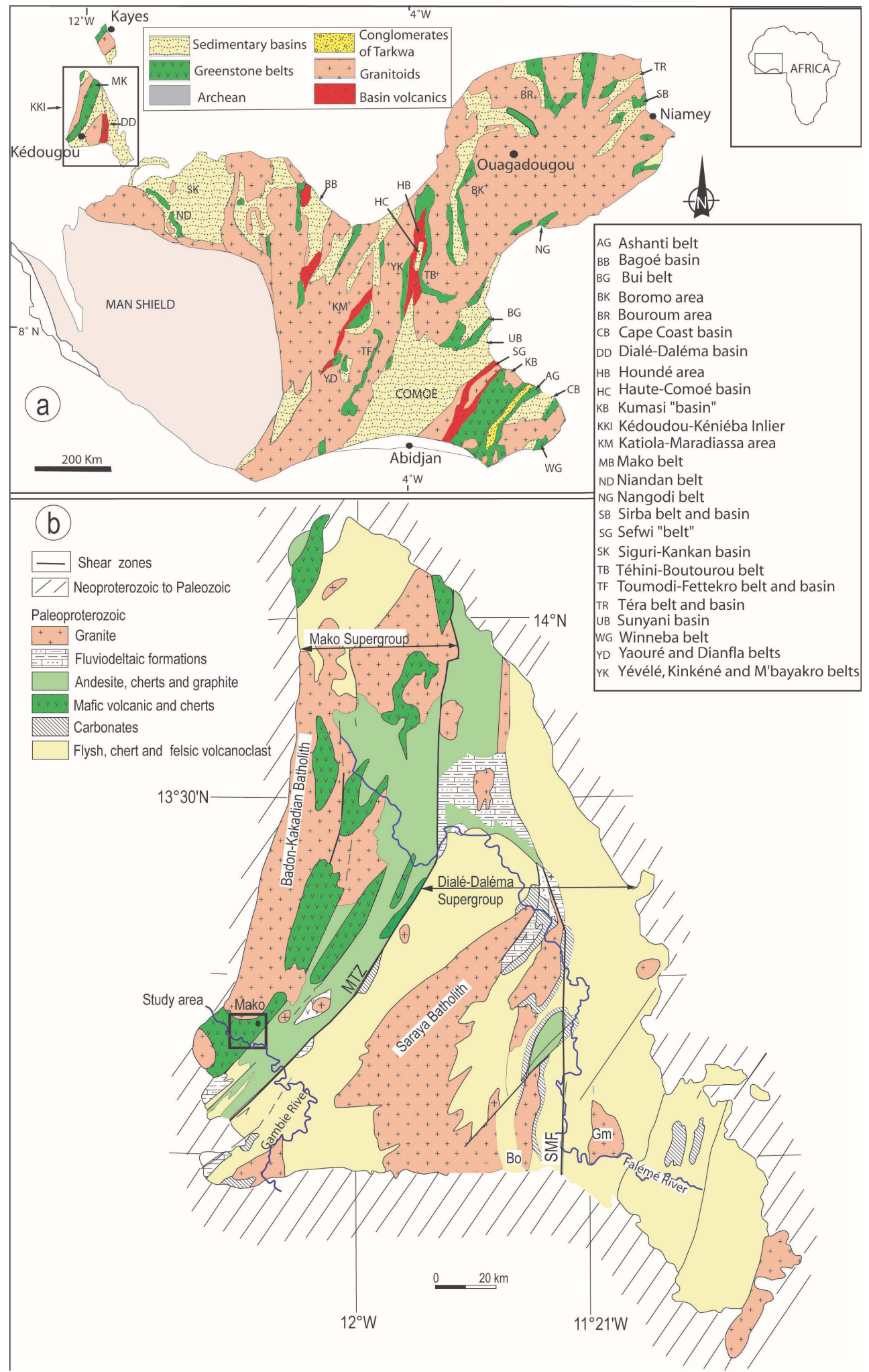

Figure 1. Kédougou-Kéniéba Inlier (KKI) in the Man shield, southern part of the West African Craton (WAC). (a) Schematic map of the major Precambrian greenstone belts of the southern part of the WAC (simplified from [17]). (b) Simplified geological map of the Birimian of KKI (modified after [26]). Rectangle delimits the study area. Bo: Boboti; Gm: Gamaye; MTZ: Main Transcurrent Zone; SMF: Senegalo-Malian Fault. 
basin of Taoudeni. The Birimian paleoproterozoic formations of the KKI are divided into two Supergroups [9] or groups [10]: West Mako and East Dialé-Daléma, which are separated by a major transcurrent zone, the MTZ (Main Transcurrent Zone) (Figure 1(b)). In this paper, we are going to use the term Supergroup to make the difference between the two entities of the KKI.

The Supergroup of Mako is a volcanoplutonic complex with tholeiitic main feature and is dated between $2213 \mathrm{Ma}$ and $2063 \pm 41 \mathrm{Ma}$ ([2] [7] [11] [12] [13]). It was the subject of many studies which have contributed to a better understanding of its lithology, petrography, geochemistry and its geochronology ([14] [15] [16] [17]). It is composed of volcanoplutonic, volcano-sedimentary and sedimentary complexes, generally metamorphosed sedimentary in the epizonal or mezonal facies in touch with the intrusions.

The volcanoplutonic sequences are bimodal and are composed of tholeitic and calco-alkaline rocks ([2] [4] [13]). The tholeiitic rocks are essentially represented by massive and pillowed metabasalts and big masses of basic and ultramafic rocks ([2] [13] [17] [18]). The calco-alkaline volcanism is composed of andesitic to felsic rocks with a lot of interbedded pyroclastic and with a volcano-detrital material ([2] [4] [9] [19]). In the lithostratigraphical feature, [17] highlighted two series in the Mako area: 1) a staple basic ophiolitic complex which is essentially composed of metaperidotites, metagabbros, metabasalts and quartzites, 2) a mixed volcanic complex at the top which consists of andesitic, rhyodacitic, and rhyolitic tuffs and lavas.

The Dialé-Daléma Supergroup is mainly sedimentary with turbiditic and carbonated metasediments which are intersected by hypovolcanic to volcanic complex mainly andesitic ([9] [20]). The sedimentary series are dated with $\mathrm{Pb}-\mathrm{Pb}$ (Zircon) method, between $2096 \pm 8$ to $2165 \pm 1 \mathrm{Ma}$ ([21] [22]). The volcanic, hypovolcanic and calco-alkaline complex [9] is dated between $2099 \pm 4 \mathrm{Ma}$ and $2072 \mathrm{Ma}$ with Zircon U-Pb and Pb-Pb methods respectively ([21] [23]). The lithostratigraphic succession of paleoproterozoic formations of the WAC and particularly that of the KKI [24] is controversial. However, most of the geochronological data obtained on the Birimian formations of KKI ([2] [12] [13] [21]) militate for a lower position of the volcanic unit of the Mako Supergroup and an upper position of the sedimentary unit of the Dialé-Daléma Supergroup. The controversial lithostratigraphy of the KKI is not directly incident to this paper.

The Birimien volcanosedimentary and volcanic are the country rocks of several generations of granitoids in coalesced massifs [25] distributed into two batholiths, Badon-Kakadian and Saraya, respectively intrusive in the Mako and Dialé-Daléma Supergroups. [10] proposed a new subdivision for the Paleoproterozoic plutonic intrusions of the KKI. They distinguish the Sandikounda-Soukouta suite $(2170$ - $2140 \mathrm{Ma})$ in the Mako Supergroup and the Saraya (2100 - $2060 \mathrm{Ma})$ and Boboti (2080 - $2060 \mathrm{Ma})$ suite in the Dialé-Daléma Supergroup. Subsequently, some post-birimian doleritic seams were emplaced in the $\mathrm{N} 20^{\circ}$ to $\mathrm{N} 80^{\circ}$ oriented structures ([13] [23]). 
This paper is aimed at the photographic study of basic enclaves and of granitoids of the Mako area with the purpose to better understand the link between the acid and basic magmatisms in the Birimian of KKI. The analysis and interpretation of field and microscopic data will allow us to get a better understanding of the evolution of the Birimian basic magmatism through the characteristics of the enclaves and their relationship with the enclosing rocks.

\section{The Lithology of Mako Area}

The Mako Sector, in the northern part of Mako Supergroup (Figure 1(b)), is a metamorphic assemblage zone primarily made up of ultramafic, mafic, intermediate and felsic rocks associated with quartzites (Figure 2). Mafic rocks are the most significant and constitute the main part of the greenstone hills between Segueko Peuls to the north and Wassadou to the south. Beside the hills made up

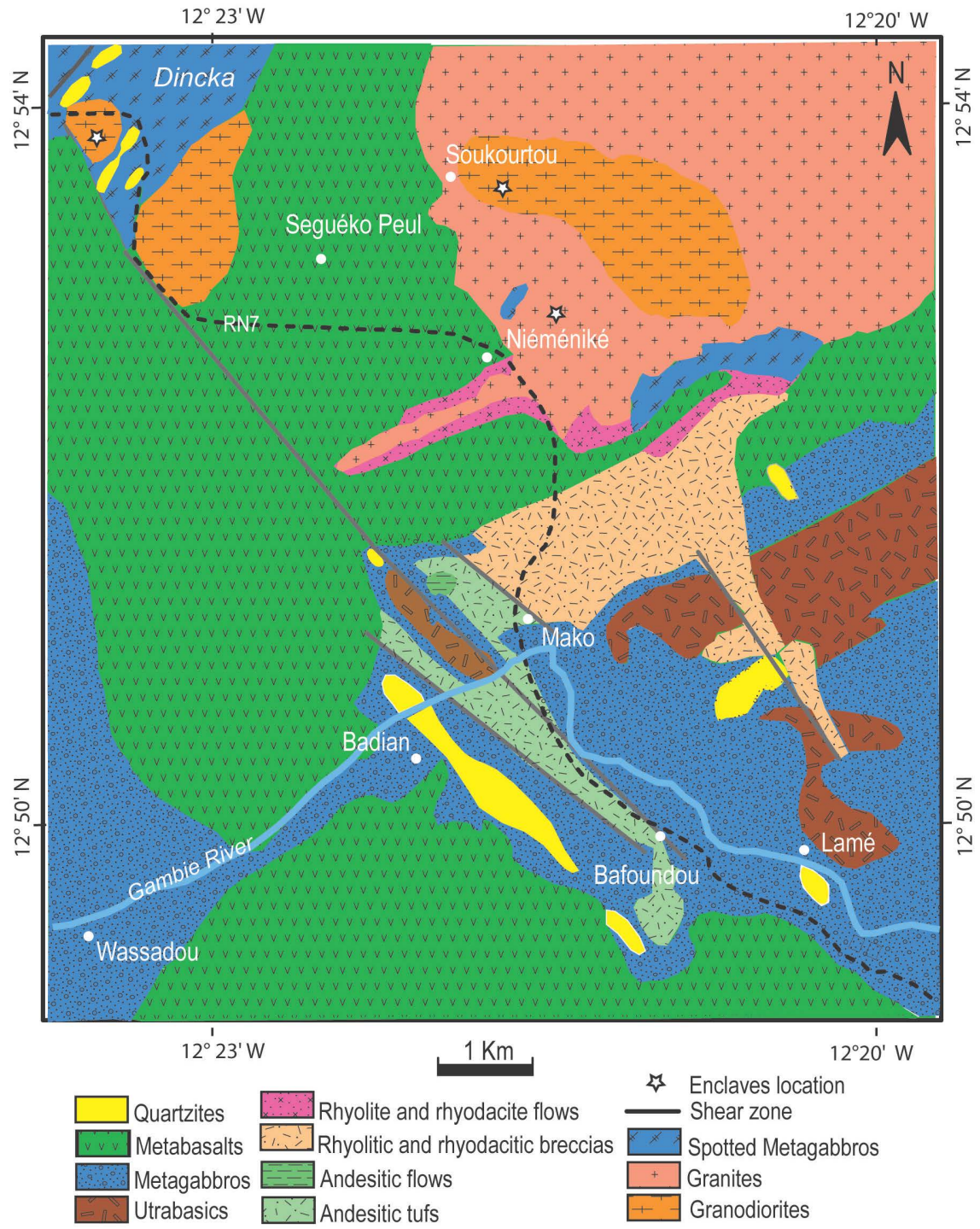

Figure 2. Geological map of the Mako Paleoproterozoic greenstone belt (modified after [17]). RN7: trunk road $n^{\circ} 7$. 
of greenstone belt mafic rocks also exposed are black ultramafic rocks of Koulountou and of Manssari-Tana forming topographic highs, to the east and west of Mako village, respectively. Kilometric lenses of quartzites, oriented NW-SE and NE-SW, are inserted locally between the mafic rocks. Andesitic breccias and felsic lavas occupy the tectonic corridors cross-cutting the ultramafic and mafic rocks. All these formations are cross-cut by several generations of granitoid's plutons which constitute the main part of the outcrops in Nieméniké village (Figure 2).

\subsection{The Ultrabasic to Basic and the Intermediary to Acid Rocks}

The ultrabasic and basic rocks constitute the most frequent terms in the West and the South parts of the study area.

Ultramafic rocks outcrop in the east sector around the village of Lamé (Koulountou hill) and the west of Mako village (Manssari-Tana hill) (Figure 2), in the shape of polygonal blocks and boulders of variable sizes. The rock surface is red to ochre in colour and exhibits severe alterations (Figure 3(a)). On a fresh
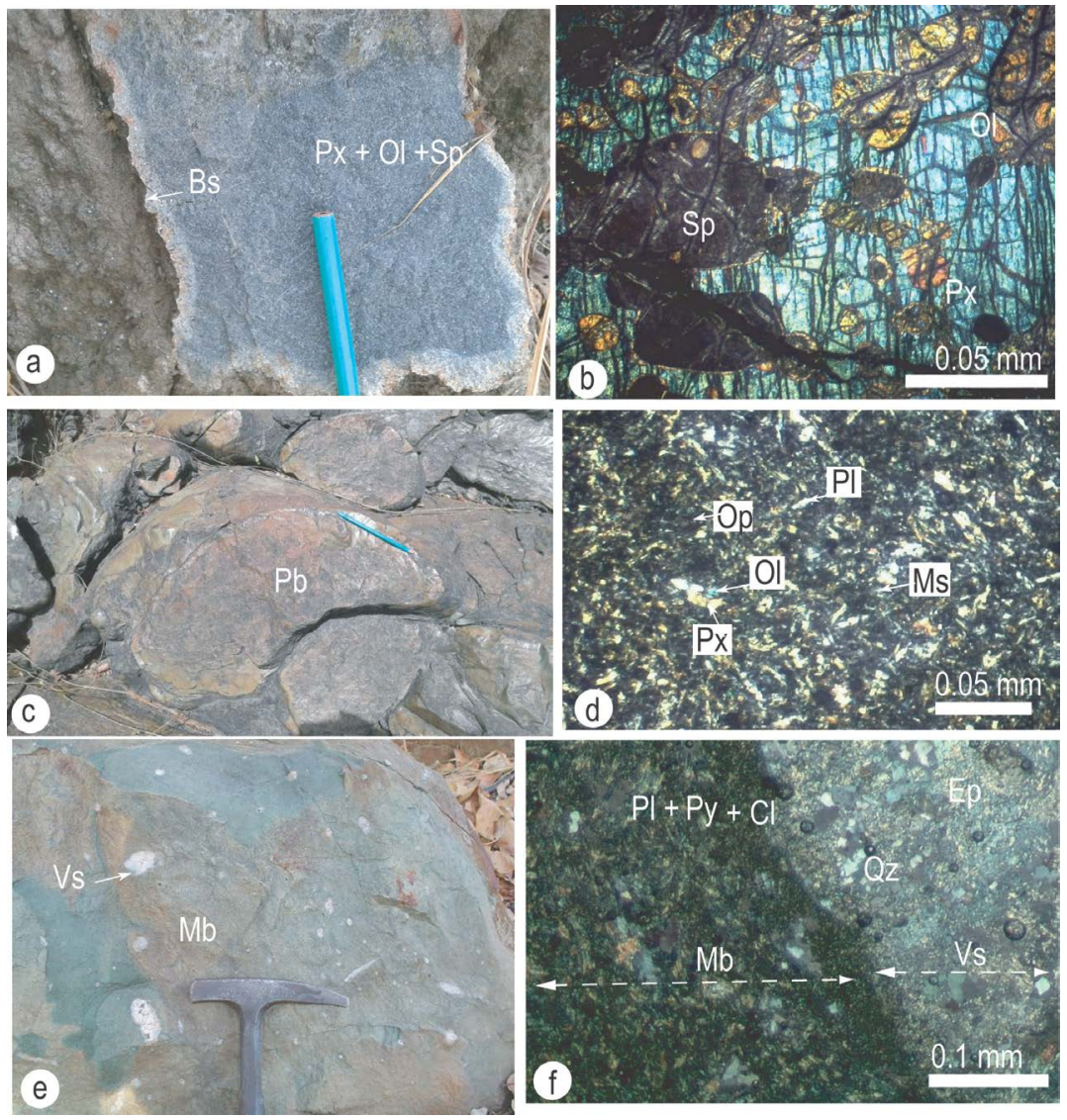

Figure 3. (a) Ultrabasic rock with whitish edges altered in serpentine (Bs); (b) microphoto of ultrabasic rock showing clinopyroxene $(\mathrm{Px})$, olivine $(\mathrm{Ol})$ and serpeninite $(\mathrm{Sp}) \mathrm{min}$ erals; (c) Pillowed metabasalt $(\mathrm{Pb})$ with an aphyric texture; (d) microphoto of pillowed aphyric metabasalt with microlithic of plagioclases ( $\mathrm{Pl}$ ), olivine and pyroxene; (e) Massive amygdalae metabasalts $(\mathrm{Mb})$ with vesicules $(\mathrm{Vs})$ in (geodes) filled of quartz $(\mathrm{Qz})$; (f) microphoto of amygdalae metabasalts with hydrothermal quartz and epidote (Ep) within the vesicule. Op: Opaque mineral. 
surface, it has a fine grained texture; with black phenocrysts of pyroxenes associated with some greenish olivine grains. The olivines are altered into a whitish crust of serpentine (Figure 3(b)).

The metabasalts show massive and pillowed structures. The pillowed metabasalts are abundantly more visible in the West of the village of Mako and appear in the shape of variable size of greenish pillows corps ranging from centimetric to metric (Figure 3(c)). The pillow-lavas body is covered by a cortex on which appear some sorts of varioles. The massif metabasalts which are more visible in the East of Mako are often with amygdalae structures (Figure 3(d)). The rock has a microlithic texture with a chloritized mesostase where appear plagioclase microliths associated with rare secondary quartz grains and pyroxene relics (Figure 3(e)). The amygdalae locally abundant comprises elliptical vesicles filled up with hydrothermal paragenesis with quartz, feldspar, chlorite, and epidote (Figure 3(f)).

The Metagabbros often crop out in the central part of the sector associated with ultramafic and metabasalts rocks (Figure 2). They have several textures equant grained, and pegmatitic with comb-layered ([27] Lofgren and Donaldson, 1975), (Figure 4). The equant grained metagabbros (Figure 4(a)) are more abundant and crop out mainly in the centre and west of Mako. They are characterized by a coarse-grained texture with amphibole, pyroxene, chlorite, plagioclase, quartz and opaque minerals (Figure $4(\mathrm{~b})$ ). The coarse-grained pegmatitic grabbros (Figure 4(c)) are more abundant towards the SE. They often show a comb-layered texture ([27] Lofgren and Donaldson, 1975) with phenocrysts of clinopyroxene arranged in sheaves leaving meshes occupied by plagioclases and secondary minerals (quartz, epidote, calcite and opaque minerals). These pegmatitic gabbros would result from differentiation of websterites and are marked by the increase in the modal composition of oxides and the increase in the size of minerals in the rock [4]. In the SE part (towards Lame) hectometric massifs of layered metagabbros conformably outcrop on the ultramafics and the pegmatitic metagabbros. They appear like amphibole-gneisses (Figure 4(d)) with granolepidoblastic texture [17], characterized by an alternation of light feldspathic minerals and ferromagnesian minerals (mainly pyroxenes, amphiboles and chlorites). Plagioclases represent the main part of light minerals and are sometimes transformed into calcite and epidote (Figure 4(e)).

A second generation of spotted metagabbros outcrop in the north part of Nieméniké (at Dinka) and cross-cut the quartzites and the granitoids. It is less rich in plagioclase and contains the mottled fine needles of pyroxenes ouralitized in amphiboles which highlight a dark mineral lineation (Figure 4(e)).

The intermediary and acid rocks outcrop mainly in the East and the north part of the area (Figure 2). They consist of a mixed volcanism (explosive and effusive) represented by andesitic, rhyodacitic and rhyolitic lavas and breccias, which crop out in tectonic corridors between Mako and Bafoundou villages.

The andesitic breccias consist of polygenic rock fragments of variable sizes 


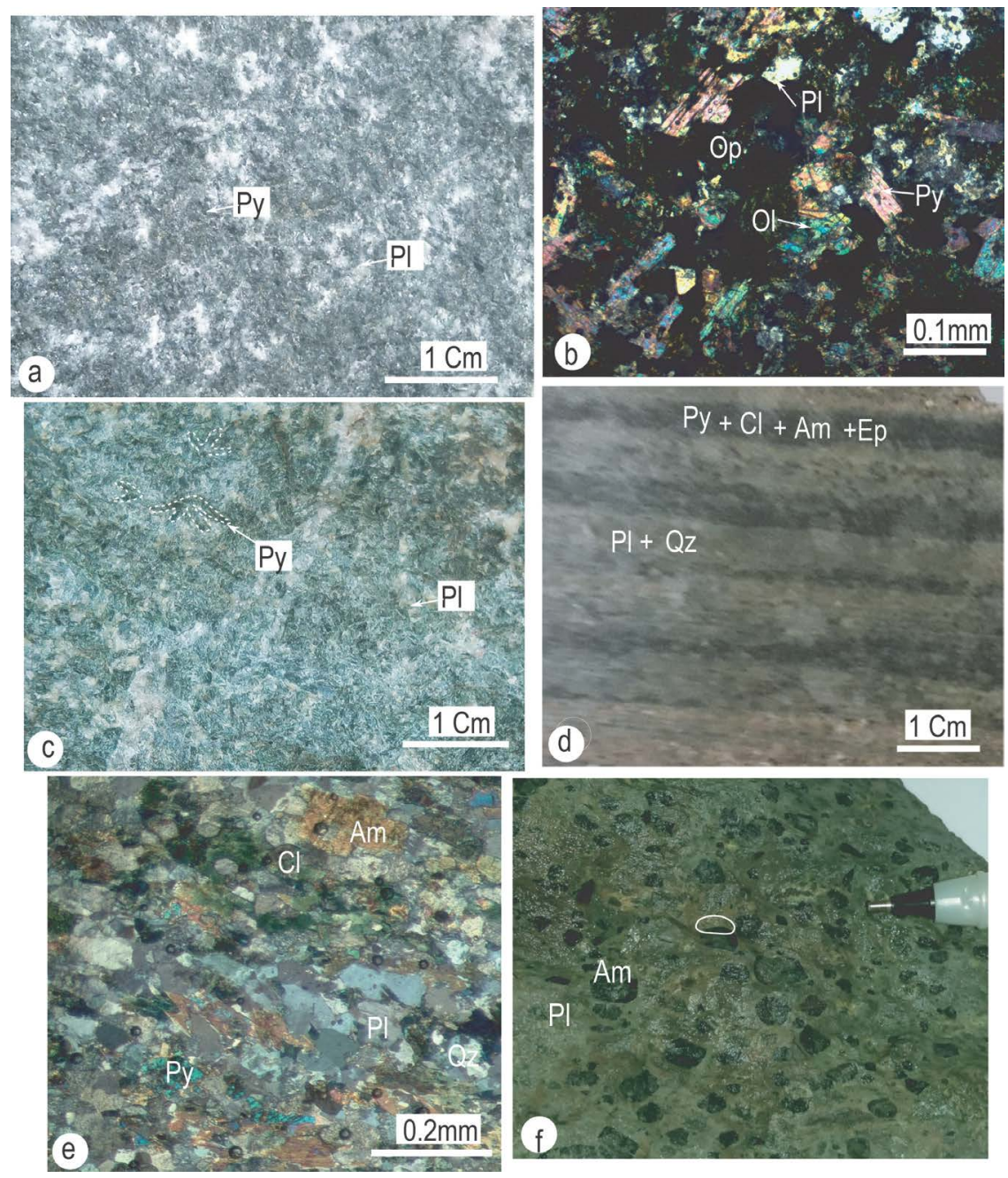

Figure 4. (a) equant grained metagabbros with pyroxene $(\mathrm{Px})$ and plagioclase $(\mathrm{Pl})$ crystals; (b) microphoto of equant grained metagabbros with grained texture composed of pyroxene, plagioclase, olivine (Ol) and opaque minerals (Op); (c) coarse grained pegmatitic grabbros which show a comb-layered texture with phenocrysts of clinopyroxene arranged in sheaves leaving meshs occupied by plagioclases; (d) layered metagabbros which appear like amphibole-gneisses with an alternation of light and dark band of feldspathic and ferromagnesian minerals respectively; (e) microphoto of layered metagabbros with granolepidoblastic texture characterized by an alternation of light feldspathic grains of Plagioclase (Pl) and quartz $(\mathrm{Qz})$ and dark ferromagnesian minerals of pyroxenes (Py), amphiboles $(\mathrm{Am})$ and chlorites $(\mathrm{Cl})$; (f) Spotted metagabbros with elongated phenocristals of amphibole $(\mathrm{Am})$ associated with plagioclase $(\mathrm{Pl})$.

(millimetric to centimetric) and rock type (sedimentary, magmatic) mainly of magmatic origin.

The andesitic breccias are interstratified with andesitic lavas which locally constitute sharpened hills in particular to the NW of Mako village. The lavas are distinguished by the presence of plagioclase and amphibole phenocrysts in a greenish mesostase (Figure 5(a)).

The rhyolite seems to be associated with the pink granite of Niéméniké. With a fresh break, the rock has a chonchoidal surface in dark brown with sharp 


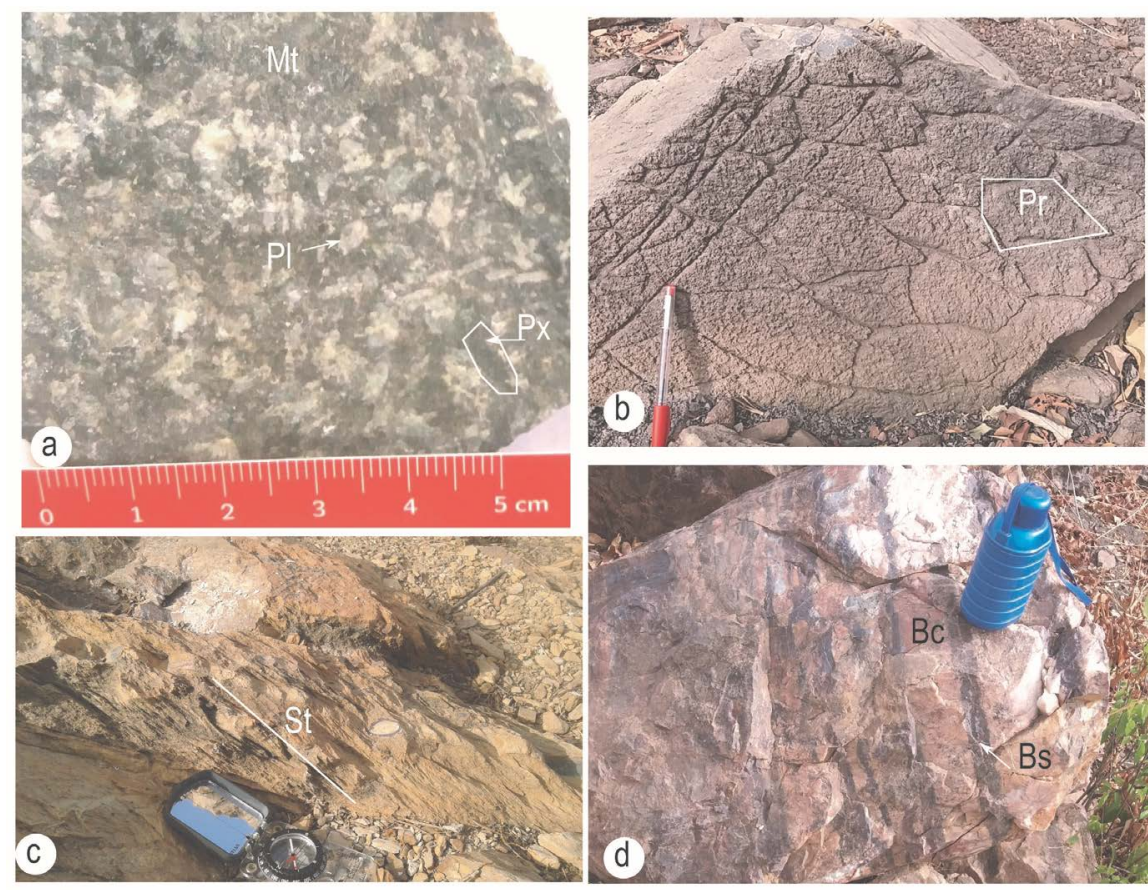

Figure 5. (a) Porphyric andesitic lava with phenocristals of plagioclases. (P1) in an aphyric mesostasis (Mt) which conceals ebony black cristals of pyroxenes. (b) Aphyric rhyolite with polygonal decametric prism structures $(\mathrm{Px})$. (c) Rhyolitic metatuff impacted by intense schistosity (St); (d) Banded quartzite which has an alteration of dark band (Bs) and light ones $(\mathrm{Bc})$.

edges. It shows locally a prismatic flow which evidence the aerial emplacement (Figure 5(b)). It has a microlitic and porphyric texture accentuated by quartz phenocristals and alkaline felsdpaths which are translucent in the dark mesostasis. These rhyolitic lavas are interstratified with rhyolitic breccias which show magmatic bedding with an alternation of fine siliceous grains and horizons made up of medium feldspathic grains (Figure 5(c)). In the SE part, the breccias and rhyolitic lavas are associated with breccias and rhyodacitic lavas. They show a porphyritic microlithic texture with feldspar phenocrysts (plagioclase and sanidine) in a mesostase strewn with plagioclase microliths, biotite and chlorite layers, as well as grains of epidote and quartz.

The sedimentary rocks are represented in the area by the banded quartzites which constitute some subvetical lenticular beds with a hectometric volume interposed in the previous volcanic and volcano-sedimentary units (Figure 2). They form elongated and discontinuous outcrops with an alternation of light and dark centimetric beds (Figure 5(d)). The texture is granoblastic, mainly made up of fine grains of quartz associated with some sericite needles. The light beds are composed of quartz and dark beds of quartz and reddish iron oxides, similar to jasperoids. Locally, conglomeratic quartzites with rare centimetric rollers are also exposed.

The whole of these Birimian formation (ultramafic, mafic, intermediate and felsic) is cross-cut by the Eburnean granitoids intrusions. 


\subsection{The Eburnean Granitoids of Mako}

The granitoids of the Mako sector mainly consist of the Niéméniké pink granite, the Soukourtou granodiorite, the Dincka leucodiorite and the Niéméniké quartzicdiorite of (Figure 2). The granitoids outcrops under decametric to metric polygonal massive blocks (Figure 6(a), Figure 6(b), Figure 6(e)).

The pink granite of Niéméniké has a grained texture (Figure 6(a)) which becomes micro-grained on the boundaries of the pluton. It is mainly composed of alkaline feldspars (orthose, microline), quartz and plagioclase. It is intersected from place to place by aplitic and pegmatitic veins which are rarely associated to dolerite dykes. It contains locally the enclaves of greenstones.
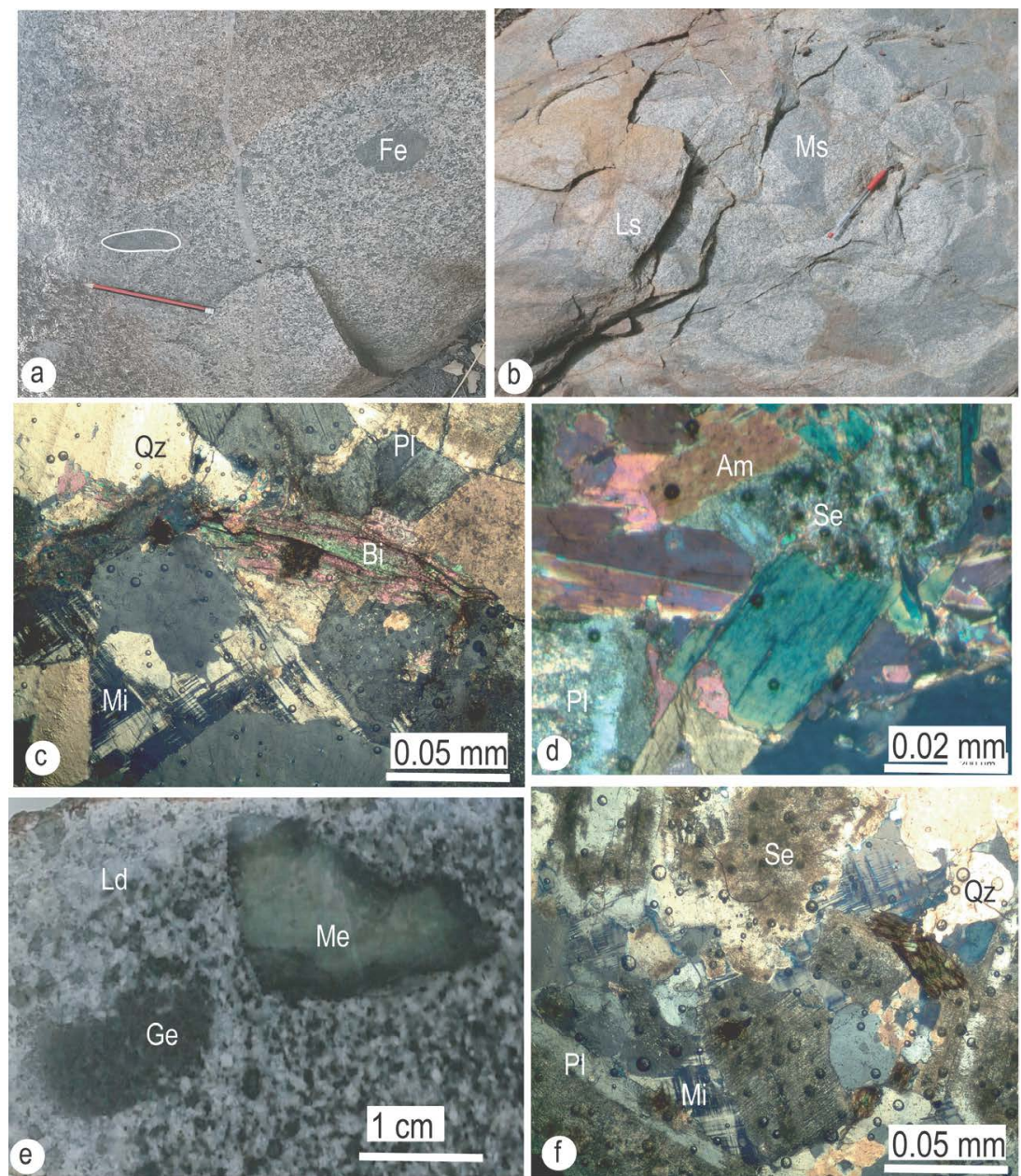

Figure 6. (a) Niéméniké granite which shows enclaves of variable dimensions stretched the same direction; (b) Soukourtou migmatitic granodiorite with whitish granodioritic (Ls) and dark gneissic, (Ms) past. (c) Microscopic aspect of the Soukourtou granidiorite with quartz $(\mathrm{Qz})$, plagioclase $(\mathrm{Pl})$, microcline $(\mathrm{Mc})$ and biotite $(\mathrm{Bt})$ minerals. (d) Microphoto of Niéméniké quartzite diorite with amphibole, plagioclase an sericite (Se) minerals; (e) Dincka leucodiorite (Lc) which has variable size of basic rocks enclaves with dark straight edges and microlitic aphyric textures $(\mathrm{Me})$ or rounded and diffused edges with a micrograined texture (Ge). (f) Dincka leucodiorite microphoto with plagioclase, sericite, microcline and quartz minerals. Me: microlitic enclave; Ge: grained enclave; Ms: mesosome; Ls: leucosome. 
The granodiorite of Soukourtou is leucocratic, but locally blended of mafic enclaves which confers it a mesocratic aspect (Figure 6(b)). On its western edge, the granodiorite is crosscuted or in contact with the orthogneissified microgranite. On thin sections, millimetre length crystals of quartz, alkaline feldspars (orthoclase, microcline), plagioclase and lengthened layers of biotite and amphibole can be distinguished (Figure 6(c)).

The quartz diorite of Niéméniké does not contain enclaves. It is essentially composed of amphibole and plagioclase megacrysts associated with some grains of quartz which are more evident on the altered surface of the rock. The rock show mainly a grained to locally pegmatic texture (Figure 6(d)).

The leucodiorite of Dincka outcrops in the North of Niéméniké village under the shape of hectometric dome which contains many enclaves of greenstones (Figure 6(e)). The leucodiorite is essentially composed of amphibole and sericitized plagioclase megacrysts with some of biotite and rare grains of quartz. The texture is mainly grained (Figure 6(f)), but locally becomes microgranular, particularly in the vicinity of the enclaves. In the parts rich in enclaves, the rock becomes mesocratic because of the rate increase of ferromagnesian minerals coming from the mafic facies.

That granite from Mako contains from place to place important quantities of enclaves of basic rocks.

\section{The Basic Enclaves in the Granitoids of Mako Area}

The enclaves are fragments of foreign rocks which are commonly called xenolith and are found in the granitoids of Mako area. They show the variables colour, size, shape and textures. We have studied them in the leucodiorite of Dincka, the granite of Niéméniké and the granodiorite of Soukourtou.

The enclaves are green, greyish or black colours. Their shapes are round, ellipsoidal, and angular with a variable size (centimetric to metric). Their texture is grained to microlitic with variable edges (limits, boundaries) shapes (straight, curvilinear, diffused). We have noticed two types of enclaves according to the shapes and characteristics of their edges in contact with the enclosing rocks: angular enclaves with straight edges and xenomorphic enclaves with uneven edges.

The angular enclaves with straight edges (Figure 6(e)) are generally dark with any preferential disposition within the granitoids. Their abundance varies from an outcrop to another.

They are less abundant and coarser in the granodiorite of Soukourtou where their size can reach some meters, and are more abundant and smaller (centimetric) in the leucodiorite and the granite of Niéméniké. They often have fracture veins filled with the recrystallization of epidote, quartz and feldspaths. The biggest part of those enclaves has a microlitic porphyritic texture composed of plagioclase microlites which sometimes are epidotized and associated with some phenocristals of pyroxene ouralitized in amphibole (Figure 7(a)). Rare relics of olivine and orthopyroxene developing a rim of green alteration, can be observed. 

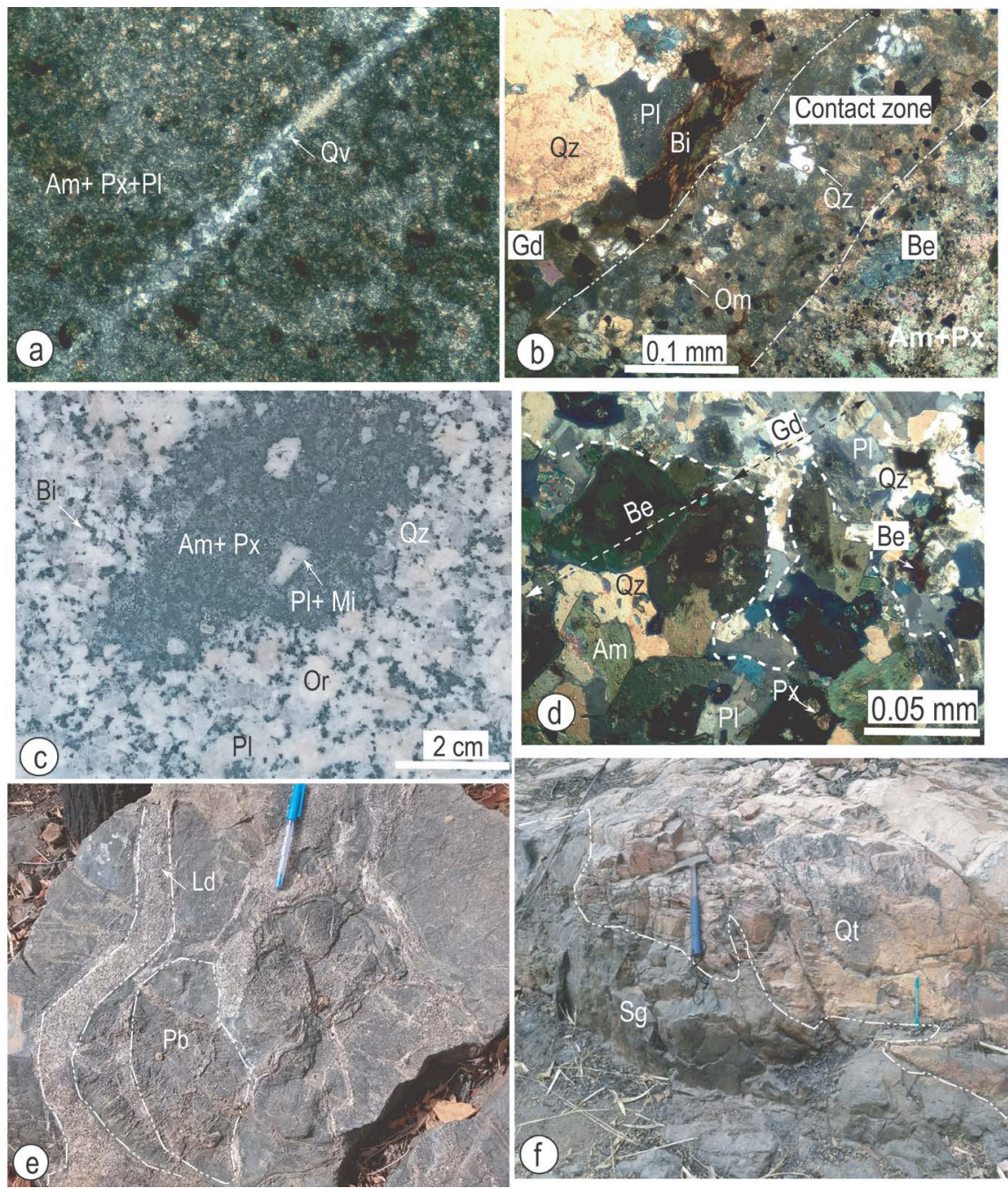

Figure 7. (a) Microlitic texture of basic enclaves in the granodiorite of Soukourtou; (b) Contact zone between straight edges basic enclaves $(\mathrm{Be})$ and the granodiorite $(\mathrm{Gd})$ which is highlighted by a sort of bun baking and a reduction of the grains sizes; (c) Basic enclaves with crenelated and diffused edges (rim) showing interpenetration between basic and acid material in the granodiorite of Dincka. (d) Microscopic aspect of the interpenetration between basic and acid material with amphibole (Am) and pyroxene (Py) floating in the feldsic cristals of plagioclases $(\mathrm{Pl})$ and of quartz $(\mathrm{Qz})$. (e) Leucodiorite (Ld) intersecting the pillowed metabasalts $(\mathrm{Pb})$. (f) Spotted metagabbros intersecting the quartzites. Bi: biotite, Mi: microline, Om: opaque minerals, Qt: quartzite, Qv: quartz vein, Sg: Spotted metagabbros.

The limit between those enclaves and the enclosing formations is often marked by rim reaction with brown cooking zone and microgranular texture separating them from the granodiorites (Figure $7(\mathrm{~b})$ ). Those characteristics (straight edge, microgranular texture in contact with enclosing rock, mafic composition) are a proof that the two magmas (basic and acid) didn't freeze at the same moment ([28] [29]). The magma of the enclaves did crystallize and freeze long before the host granitic one.

The origin of those enclaves is thought to fragments of the basic enclosing 
rocks (metabasalts, metagabbros) washed away by the granitic magma on its ascent or fallen from the roof of the basic outcrops into the granitic magma.

The enclave with uneven (irregular) and diffused edges are generally scattered, permeated, slashed by the granitic magma (Figure 6(c)). They are generally of small size (centimetric to decimetric) and their contact with the granitoids is often diffused or soft [29] (Figure 7(c)). In the granodiorite of Soukourtou they are generally small in size (centimetric) with a mesocratic colour (greyish to greenish) and a microgranular to granular texture. They are abundant in the leucodiorite of Dincka where their size can reach many centimeters. Locally they seem to be oriented in a preferential direction (Figure 6(a)).

Observed through the microscope, they are composed of plagioclase, amphibole (actinote), epidote and sometimes secondary quartz (Figure 7(d)). In some places, minerals of the enclaves (amphibole, pyroxene) are locally trapped in the granite (Figure $7(d)$ ). Inversely, granite fragments composed of plagioclase and quartz are sometimes isolated within the enclaves (Figure $7(\mathrm{c})$ ). So these basic enclaves have in them the elements of granite. The fact that the basic enclaves with curvilinear edges content of the granite (plagioclase and quartz minerals) proves that the granitic and the basaltic magmas were still liquid (at least partially) when the feldspaths and the quartz of the granite entered mechanically in the basic enclave.

That hybrid relationship between the granitoids and the enclaves with curvilinear edges supposes that they are co-magmatic and the granitic magma and the basic one were liquid or partly liquid at the same moment. However, due to their different density and viscosity they hardly mixed.

\section{Discussion and Petrogenetic Implications in the Birimian of KKI}

\subsection{Discussion}

The enclaves of basic rocks trapped in the granitoids of Mako area have variable characteristics (shape, texture, dimension etc.). We have noticed two types of enclaves: the angular enclaves with straight edges (ante-granitoids) and soft enclaves with uneven edges (syn-granitoids).

The enclaves with straight edges and well sliced in the enclosing formations (Figure 6(e)) have often a microlitic texture (Figure 7(a)) with secondary minerals (amphibole, epidote) and some relics of primary minerals (pyroxene, olivine). Those enclaves are generally big in size (decimetric to metric) and may come from the fragments of the basic volcanic formations which are already consolidated, fragmented, torn away and transported in the granitoids. That's why we call them ante-granitoids enclaves (or xenoliths). The outcrops of the enclosing formations are constituted of metabasalts and metagabbros which are locally intersected by granitoids (Figure 7(e)).

The enclaves with curvilinear edges are more visible in the granitoids of Mako area. They are characterized by round, elliptical, lobe or crenelated edges which 
are relative to a soft contact between two contemporary magmas, the one felsic and corresponds to the granitic host and the other mafic which forms the enclaves (Figure $7(\mathrm{c})$ ). In fact certain enclaves of the granitoids are considered as a testimony of the coexistence of basic, acid and non-consanguineous magmas but co-genetics. Therefore we can call them syn-granitoids enclaves (co-magmatic).

Other authors ([30] [31]) suggest that the micrograined and mafic enclaves is the residual material of the crustal and unmelted rocks during the processes which led to the granitoids magma. On the other hand, authors like [32] and [33], consider the enclaves as fragments formed during the cristal-liquid differentiation which occurred in a magmatic chamber.

Furthermore, the immiscibility of the liquid in an intermediary magmatic chamber was put forward to explain the origin of the enclaves [34] [35]. That immiscibility of liquids is identified by the mineralogy and texture differences between the enclaves and the host rocks as well as the associations with structures such as the folding of the edges. However, the magmatic interaction has become the most commonly model proposed to interpret the origin of the enclaves. The round and diffused edges of the enclaves indicate that the magma of various viscosity existed in the same magmatic system. Besides big crystals of plagioclase intersected the limit enclave-host, the round and irregular or diffuse edges are often visible and are also considered to prove the liquid state of the enclaves during their incorporation in the more felsic magma which produced the granitoids (Figure 7(c), Figure 7(d)).

\subsection{Petrogenetic Implications in the Birimian of KKI}

The existence of at least two generations of enclaves of basic rocks (ante and syn-granitoids) in the granitoids is a testimony of at least two generations of basic magmatism in the Paleoproterozoic formations of the Kédougou-Kéniéba inlier. In fact, the available geochronological data on the basic rocks of KKI give an age $\mathrm{Pb} / \mathrm{Pb}$ on Whole Rocks (RW) of $2197 \pm 11 \mathrm{Ma}$ [2] and Sm/Nd (WR) of 2063 $\pm 41 \mathrm{Ma}$ [7]. The first ages are attributed to the emplacement of pillowed and massives metabasalts, and the metagabbros which are associated with them. These metabasalts and metagabbros would be co-magmatic [4]. On the field, they have a petrographic continuity, and a progressive textural variation (from metagrabbros to metamicrogabbros and metabasalts) and a narrow spatial association. All those basic rocks have a tholeiitic geochemical affinity with a light enrichment in highly hygromagmaphile elements and in LREE for the massive basalts [4]. Those associated basic rocks (metabasalts, metagabbros) would constitute the enclaves with straight edges (ante-granitoids) which are found in the granitoids of Mako. Those enclaves are generally of big size with a variable texture according to their volcanic or plutonic origin.

Furthermore, the quartzites which constitute the top part of those associated basic rocks (pillowed to massive metabasalts and metagabbros) are locally intersected by a second generation of metagabbros which are spotted with secondary 
amphibole (Figure 4(f), Figure 7(f)). That spotted metagabbros which intersects the quartzites may be more recent than the metagabbros associated with pillowed and massive metabasalts. The geochronological data which exist about the basic series of the Birimian rocks of Mako give an Sm/Nd (WR) age of 2063 $\pm 41 \mathrm{Ma}$ [7] to the second phase of the basic magmatism. Those second basic rocks would be established at the same moment with the Eburnean granitoids of Saraya and Boboti batholiths dated with U-Pb (zircon) between 2100 and 2060 $\mathrm{Ma}$ [13]. In fact that granitoids have a lot of co-magmatic basic enclaves often oriented in the preferential direction (Figure 6(a)).

\section{Conclusion}

Thus, we can consider for the basic magmatism of the Birimian of KKI, there would be at least two periods of emplacements. The first is related to the formation of the massive and pillowed metabasalts and the associated metagabbros. The second phase of basic magmatism would be (contemporaneous) co-genetics of granitoids of Saraya and Boboti which are rich in scattered, fusiform and elongated basic enclaves. The hybridization of these two contemporary basic and acid magmas can generate large volumes of magmas with intermediate composition. These magmas are at the origin of syntectonic granitoids which contain the elongated basic enclaves. This diversity of the basic volcanism of the Birimian of KKI was also highlighted by [4] who pinpointed a precocious basic volcanism associated to the oceanic basin (oceanic plateaus) and a late subaerial basic vocanism associated with the intermediary to acid magmatism in back arc basins. In Guinea, two basic volcanisms are distinguished in the Birimian formations. They consist of the Nandian volcanic belt which is composed of a basic and ultrabasic suite established in an anorogenic context ([36] [37]) and the basic suite of the Siguiri-Kankan basin which is dated to $2096 \mathrm{Ma}$ [38]. These questions about the diversity of the basic magmatism of the Birimian and those about the mixture of acid and basic magmas in the Paleoproterozoic formations of the WAC will be better elucidated by enough geochemical and geochronological data in order to better constrain the magmatic evolution of the Birimian formations in the West African Craton.

\section{Acknowledgements}

We would like to express our grateful thanks to UNESCO. Many thanks to Professor A. Mané for her help with the English.

\section{Conflicts of Interest}

The authors declare no conflicts of interest regarding the publication of this paper.

\section{References}

[1] Bassot, J.P. (1966) Etude Géologique du Sénégal Oriental et de Ses Confins 
Guinéo-Maliens. Mémoire du BRGM, No. 40, 332 p.

[2] Dia, A., Van Schmus, W.R. and Kröner, A. (1997) Isotopic Constraints on the Age and Formation of a Paleoproterozoic Volcanic Arc Complex in the Kedougou Inlier, Eastern Senegal, West Africa. Journal of African Earth Sciences, 24, 197-213. https://doi.org/10.1016/S0899-5362(97)00038-9

[3] Ledru, P., Pons, J.P., Milési, J.P., Dommanget, A., Johan, V., Diallo, M. and Vinchon, C. (1989) Tectonique Transcurrente et Évolution Polycyclique dans le Birimien, Protérozoique Inférieur du Sénégal-Mali (Afrique de l'Ouest). Comptes Rendus de P Académie des Sciences, 308, 117-122.

[4] Ngom, P.M. (1995) Caractérisation de la Croûte Birimienne dans les Parties Centrale et Méridionale du Supergroupe de Mako. Implications Géochimiques et Pétrogénétiques. Thèse d’Etat Université Cheikh Anta Diop, Dakar-Sénégal. 240 p.

[5] Kitson, A.E. (1928) Provisional Geological Map of the Gold Coast and Western Togoland with Brief Descriptive Notes. Gold Coast. Geological Survey Bulletin, 2, $13 \mathrm{p}$.

[6] Bessoles, B. (1977) Géologie de l'Afrique. Le Craton Ouest-Africain. Mémoires $B R G M$, Paris, 88 p.

[7] Abouchami, W., Boher, M., Michard, A. and Albarède, F. (1990) A Major 2.1 Ga Old Event of Mafic Magmatism in West Africa: An Early Stage of Crustal Accretion. Journal of Geophysical Research: Solid Earth, 95, 17605-17629. https://doi.org/10.1029/JB095iB11p17605

[8] Liégeois, J.P., Claessens, W., Camara, D. and Klerx, J. (1991) Short-lived Eburnian Orogeny in Southern Mali. Geology, Tectonics, U-Pb and Rb-Sr Geochronology. Precambrian Research, 50, 111-136. https://doi.org/10.1016/0301-9268(91)90050-K

[9] Bassot, J.P. (1987) Le Complexe Volcano-Plutonique Calco-Alcali de la Rivière Daléma (Est Sénégal): Discussion de sa Signification Géodynamique dans le Cadre de L’Orogénie Eburnéenne (Protérozoïque Inférieur). Journal of African Earth Sciences (1983), 6, 505-519. https://doi.org/10.1016/0899-5362(87)90091-1

[10] Théveniaut, H., Ndiaye, P.M., Buscail, F., Couëffé, R., Delor, C., Fullgraf, T. and Goujou, J.-C. (2010) Notice Explicative de la Carte Géologique du Sénégal Oriental à 1/500 000. Ministère des Mines, de l'Industrie, de l'Agro-Industrie et des PME, Direction des Mines et de la Géologie, Dakar.

[11] Bassot, J.P. and Caen-Vachette, M. (1984) Données Géochronologiques et Géochimiques Nouvelles sur les Granitoïdes de l'Est du Sénégal: Implications sur l'Histoire du Birimien de Cette Région. In: Klerkx, J. and Michot, J., Eds, Géologie Africaine Tervuren, 191-209.

[12] Gueye, M., Siegesmund, S., Wemmer, K., Pawlig, S., Drobe, M., Nolte, N. and Layer, P. (2007) New Evidences for an Early Birimian Evolution in the West African Craton: An Example from the Kédougou-Kénieba Inlier, Southeast Sénégal. South African Journal of Geology, 110, 511-534. https://doi.org/10.2113/gssajg.110.4.511

[13] Delor, C., Couëffé, R., Goujou, J.-C., Diallo, D.P., Théveniaut, H., Fullgraf, T., Ndiaye, P.M., Dioh, E., Blein, O., Barry, T.M.M., Cocherie, A., Le Métour, J., Martelet, G., Sergeev, S. and Wemmer, K. (2010) Notice Explicative de la Carte Géologique à 1/200 000 du Sénégal, Feuille Saraya-Kédougou Est. Ministère des Mines, de l'Industrie, de l'Agro-Industrie et des PME, Direction des Mines et de la Géologie, Dakar.

[14] Ngom, P.M. (1985) Contribution à l'Étude de la série Birimienne de Mako dans le Secteur de Sabodala (Sénégal Oriental). Thèse de 3éme Cycle. Université de Nancy I, Nancy, 134 p. 
[15] Dia, A. (1988) Caractère et Signification des Complexes Magmatiques et Métamorphiques du Secteur de Sandikounda-Laminia (Nord de la Boutonnière de Kédougou, Est du Sénégal): Un Modèle Géodynamique du Birimien de l'Afrique de l'Ouest. Thèse Université Dakar, Sénégal, 350p.

[16] Dioh, E. (1995) Caractérisation, Signification et Origine des Formations Birimiennes Encaissantes du Granite de Dioumbalou (Partie Septentrionale de la Boutonnière deKédougou-Sénégal Oriental) Thèse d'Etat. Université Cheikh Anta Diop, Sénégal, $445 \mathrm{p}$.

[17] Dabo, M., Aïfa, T., Nging, I., Faye, M., Ba, M.F. and Ngom, P.M., (2017) Lithological Architecture and Petrography of the Mako Birimian Greenstone Belt, Kedougou-Kenieba Inlier, Eastern Senegal. Journal of African Earth Sciences, 131 128-144. https://doi.org/10.1016/j.jafrearsci.2017.04.005

[18] Hirdes, W., Davis, D.W., Lüdtke, G. and Konan, G. (1996) Two Generations of Birimian Paleoproterozoic Volcanic Belts in Northeastern Côte d'Ivoire West Africa: Consequences for the Birimian Controversy. Precambrian Research, 80, 173-191.

[19] Diallo, D.P. (1994) Caractérisation d'une Portion de Croûte d'âge Protérozoïque Inférieur du Craton Ouest Africain: Cas de l'Encaissant des Granitoïdes dans le Supergroupe de Mako (Boutonnière de Kédougou). Implications Géodynamiques. Thèse d'Etat, University of Dakar, Dakar, 466 p.

[20] Dabo, M. (2011) Tectonique et Minéralisations Aurifères dans les Formations Birimiennes de Frandi-Boboti, Boutonnière de Kédougou-Kéniéba, Sénégal. PhD thesis. University of Rennes 1, Rennes, 233 p.

[21] Hirdes, W. and Davis, D.W. (2002) U/Pb Geochronology of Paleoproterozoic Rocks in the Southern Part of the Kedougou-Kéniéba Inlier, Senegal, West Africa: Evidence for Diachronous Accretionary Development of the Eburnean Province. Precambrian Research, 118, 83-99. https://doi.org/10.1016/S0301-9268(02)00080-3

[22] Calvez, J.Y., Feybesse, J.L., Ledru, P. and Milési, J.P. (1990) Géochronologie du Protérozoïque Inférieur du Craton Ouest Africain (Méthode d'Évaporation Directe de Zircons Isolés). $13^{\text {ème }}$ R.S.T., Grenoble, Abstract, 26.

[23] Bassot, J.P., Cantagrel, J.M. and Jamond, C. (1986) Les Nouvelles Données Géochronologiques sur les Dolérites et Gabbros de l'Est Sénégal et de la Guinée Bissau: Réflexion sur l'âge de la Mise en Place et la Répartition du Magmatisme Tholéitique “Continental” à l'Échelle de l'Afrique de l'Ouest. Garcia de Orta, Série de Geologia, 9, 1-14.

[24] Milési, J.P., Diallo, M., Feybesse, J.L., Keita, F., Ledrur, P., Vinchon, C. and Dommanget A. (1986) Caractérisation Lithostructurale de Deux Ensembles Successifs dans les Séries Birimiennes de la Boutonnière de Kédougou (Mali-Sénégal) et de Nianda (Guinée): Implications Gîtologiques. CIFEG Occasional Publication, 10, 113-121.

[25] Gueye, M., Ngom, P. M., Diene, M., Thiam, Y., Siegesmund, S., Wemmer, K. and Pawlig S. (2008) Intrusive rocks and Tectono-Metamorphic Evolution of the Mako Paleoproterozoic Belt (Eastern Senegal, West Africa). Journal of African Earth Sciences, 50, 88-110. https://doi.org/10.1016/j.jafrearsci.2007.09.013

[26] Pons J., Oudin, C. and Valéro, J. (1992) Kinematics of Large Syn-Orogenic Intrusions: Example of the Lower Proterozoic Saraya Batholith (Eastern Senegal). Geologische Rundschau, 81, 473-486. https://doi.org/10.1007/BF01828610

[27] Lofgren, G. and Donaldson, C.H. (1973) Experimental Evidence Bearing on the Origin of "Comb (Willow Lake) Layering". Geological Society of America, Abstracts with Programs, 5, 716.

[28] Pitcher, W.S. (1993) The Nature and Origin of Granite. Blackie, London, 322 p. 
[29] Nedelec, A. and Bouchez, J.L. (2011) Pétrologie des Granites, Structure, Cadre Géologique. Société Géologique de France, Vuibert, Paris, 306 p.

[30] Vernon, R.H. (1983) Restite, Xenoliths and Microgranitoids Enclaves in Granites. Journal and Proceedings of the Royal Society of New South Wales, 116, 77-103.

[31] White, A.J.R., Chappell, B.W. and Wyborn, D. (1999) Application of the Restite Model to the Deddick Granodiorite and Its Enclaves-A Reinterpretation Oh the Observation and data of Maas, et al. (1977). Journal of Petrology, 40, 413-421. https://doi.org/10.1093/petroj/40.3.413

[32] Dahlquist, J.A. (2002) Mafic Microgranular Enclaves: Early Segregation from Metaluminous Magma (Sierra de Chepes), Pampean Ranges, NW Argentina. Journal of South American Earth Sciences, 15, 643-655. https://doi.org/10.1016/S0895-9811(02)00112-8

[33] Fershtater, G.B. and Borodina, N.S. (1991) Enclaves in the Hercynian Granitoidss of the Urals Mountains. In: Didier. J. and Barbarin, B. (Eds.), Enclaves and Granite Petrology, Elsevier, Amsterdam, 83-94.

[34] Bender, J.F., Hanson, G.N. and Bence, A.E. (1982) The Cortlandt Complex: Evidence for Large-Scale Liquid Immiscibility Involving Granodiorite and Diorite Magmas. Earth and Planetary Science Letters, 58, 330-344. https://doi.org/10.1016/0012-821X(82)90084-X

[35] Mezger, K., Alther, R., Okrusch, M., Henjes-Kunst, F. and Kreuzer, H. (1985) Genesis of Acid/Basic Rock Associations: A Case Study. The Kallithea Intrusive Complex, Samos, Greece. Contributions to Mineralogy and Petrology, 90, 353-366. https://doi.org/10.1007/BF00384714

[36] Tegyey, M. and Johan, V. (1989) Une Séquence Komatiitique dans le Protérozoïque Inférieur de la Guinée (Afrique de l'Ouest): Caractères Pétrographiques, Minéralogiques et Géochimiques. Comptes Rendus Académie Sciences, Paris, 193-203.

[37] Thiéblemont, D. (1989) Géochimie des Chaînons Volcaniques de Niandian et Kéniéro (Birimien de Guinée) Comparaison avec le Magmatisme Birimien de Côte d'Ivoire et du Sénégal. Implications Géodynamiques. Notes BRGM DAM/DEX No. MII.

[38] Feybesse, J.L., Bangoura, A., Billa, M., Costea, C.A., Diabète, B., Diaby, S., Diallo, A., Diallo, S., Diallo, A.B., Egal, E., Freyssinet, P., Gaye, F., Guerrot, C., Iliescu, D., Lacomme, A., Lahondière, D., Le Berre Milesi, J.P., Minthé, D. and Soumah, D. (1999) BRGM, DNRGH. Notice Explicative de la Carte Géologique de la Guinée à 1/200000. Feuille No. 19, Ministères des Mines, de la Géologie et de l'Environnement, Kankan, 27 p. 